\title{
Harttia merevari, a new species of catfish (Siluriformes: Loricariidae) from Venezuela
}

\author{
Francisco Provenzano R.*, Antonio Machado-Allison*, Barry Chernoff**, \\ Phil Willink***, and Paulo Petry****
}

Harttia merevari, a new species of loricariid catfish, is described from eight specimens captured in the upper Caura River, Orinoco River basin, Venezuela. The new species is recognized by the following combination of characters: abdomen naked; two or three preanal plates; a bony plate before each branchial opening; seven lateral plates between the pectoral and pelvic fins; maxillary barbel short and attached to the oral disk by a fleshy fold; head dorsal surface and anterior portion of the body light or dark yellow with numerous, round black spots; posterior region of the body light or dark yellow with five black transverse bands, dorsal central area of the two anterior bands diffused. The discovery of this new species extends the distribution of the genus northwest to include the Orinoco River basin on the northern slope of the Guyana shield.

Harttia merevari, uma espécie nova de bagre loricarideo é descrita com base em oito exemplares capturados no alto rio Caura, bacia do rio Orinoco, Venezuela. A espécie nova se distingue pela seguinte combinação de caracteres: abdome nu; duas ou três placas preanais; presença de uma placa óssea anterior a cada abertura branquial; sete placas laterais entre as nadadeiras peitorais e pélvicas; barbilhão maxilar curto e unido ao disco oral por uma dobra carnosa; superfície dorsal da cabeça e região anterior do corpo amarelo escuro ou marrom claro com numerosos pontos negros arredondados, região dorsal e posterior do corpo amarelo escuro ou marrom claro com cinco bandas transversais negras, as duas bandas anteriores com a parte dorsocentral difusa. A descoberta desta espécie nova estende a distribuição do gênero ao noroeste incluindo a bacia do rio Orinoco na vertente norte do Escudo das Guianas.

Key Words: Taxonomy, Harttiini, Caura River, Orinoco River basin, Guyana shield, Biogeography.

\section{Introduction}

During two expeditions to the Caura River, Bolívar State (IZT UCV-FMNH, 1993 and AquaRAP, 2000), specimens were captured representing a new species of loricariid catfish of the genus Harttia Steindachner (1877). Harttia belongs to the Harttiini of the Loricariinae (Boeseman, 1971; Isbrücker, 1980) and the type species is H. loricariformis (type locality: Paraíba do Sul River, southeastern Brazil). The only known species from Venezuela is Harttia platystoma (Günther, 1868), which is restricted to the Cuyuní River basin (MachadoAllison et al., 2000).

While placement of species within the Harttiini is relatively unambiguous (e.g., Boeseman, 1971, 1976; Isbrücker,
1975, 1980, 2001; Isbrücker \& Nijssen, 1979, in Isbrücker, 1979; Oyakawa, 1993; Langeani et al., 2001; Rapp Py-Daniel \& Oliveira, 2001; and Ferraris, 2003) the recognition of genera and assignment of species to a genus has been controversial (e.g., recognition of Cteniloricaria Isbrücker \& Nijssen, 1979 or Quiritixys Isbrücker et al. 2001 as distinct from Harttia). We agree with Rapp Py-Daniel \& Oliveira (2001) and recognize 21 previously described species of Harttia (Table 1).

In this paper Harttia merevari is described from the upper Caura River, Bolívar State, Venezuela. The presence of this new species of Harttia in the Venezuelan portion of the Guyana Shield elevates the number of Harttia species to 22, and increases the northwestern geographic distribution boundary for the genus.

\footnotetext{
* Instituto de Zoología Tropical, Universidad Central de Venezuela, Apartado 47058, Caracas 1041-A, Venezuela. e-mail: fprovenz@strix.ciens.ucv.ve; amachado@strix.ciens.ucv.ve

** Department of Biology \& Dept. Earth \& Environmental Sciences, Wesleyan University, Middletown, CT 06459. e-mail: bchernoff@wesleyan.edu *** Department of Zoology, Field Museum, 1400 S. Lake Shore Dr., Chicago IL 60605, USA. e-mail: pwillink@fieldmuseum.org **** Department of Ichthyology, Museum of Comparative Zoology Harvard University, 26 Oxford St., Cambridge, MA 002138, USA. email: ppetry@oeb.harvard.edu
} 


\section{Materials and Methods}

The specimens used in this work are deposited at the following ichthyological collections: Museo de Biología de la Universidad Central de Venezuela, Colección de Peces (MBUCV-V) and Field Museum of Natural History (FMNH). Measurements and counts are those described by Boeseman (1971). The measurements were taken with a digital caliper. Counts, observations, and drawings of external morphology were done using a stereoscopic microscope. Comparisons of external morphology and morphometric and meristic data were carried out using original descriptions plus specimens of Harttia from FMNH and specimens of $H$. platystoma and $H$. guianensis deposited at MBUCV.

\section{Harttia merevari, new species \\ Figs.1-2}

Holotype. MBUCV-V-26578, 99.4 mm SL. Venezuela, Bolívar State, Caura River at the top of Salto Pará waterfalls, among rocks on the eastern side of the river, 17 Sep 1993, C. Silvera, F. Provenzano, A. Machado-Allison, B. Chernoff, H. LópezRojas \& A. Rojas.

Paratypes. MBUCV-V-30850, 4, (68.4-88.8 mm SL) and FMNH 116484, 3, (66.5-81.2 mm SL). Venezuela, State Bolívar, Caura River, near the top of Salto Pará waterfalls, among rocks on the eastern side of the river, 30 Nov 2000, A. Machado-Allison, F. Provenzano, B. Chernoff, \& A. Rojas.
Diagnosis. Harttia merevari is distinguished from all congeners by the following combination of external characters: abdomen naked; two or three preanal plates, triangular, rectangular or square in shape; smaller plates, variable in number, arrangement and shape, present anterior to preanal plates, particularly in smaller specimens; broad triangular plate present anterior to each branchial opening; seven lateral (thoracic) plates between the pectoral and pelvic fins; maxillary barbels short, united to oral disk with fleshy flap; dorsal surface of head and anterior portion of body light or dark yellow with numerous black spots; dorsal and posterior portion of body light or dark yellow with five black transverse bands; anterior two bands with a diffused central portion; and caudal fin forked

Description. Morphometric data presented in Table 2. Head and body depressed. In dorsal view, body slender (Fig.1); cleithral width $20.39 \%$ SL (4.91 times SL). Snout rounded, contour oval in dorsal view. Supraorbital border raised. Interorbital area and supraoccipital flat. Lip margins undulated slightly. Lip surfaces covered with papillae, except small naked region near dentary. Teeth numerous, 50 or more in each dentary. Teeth very thin and elongate, forked and asymmetric with inner lobe larger and rounded; apex arched toward interior of mouth and yellowish, while rest of tooth whitish. Interior of mouth with only one small elongated papilla on roof of mouth, located midline between premaxillaries and oral valve. Very small maxillary barbel joined to inferior lip by thin fleshy

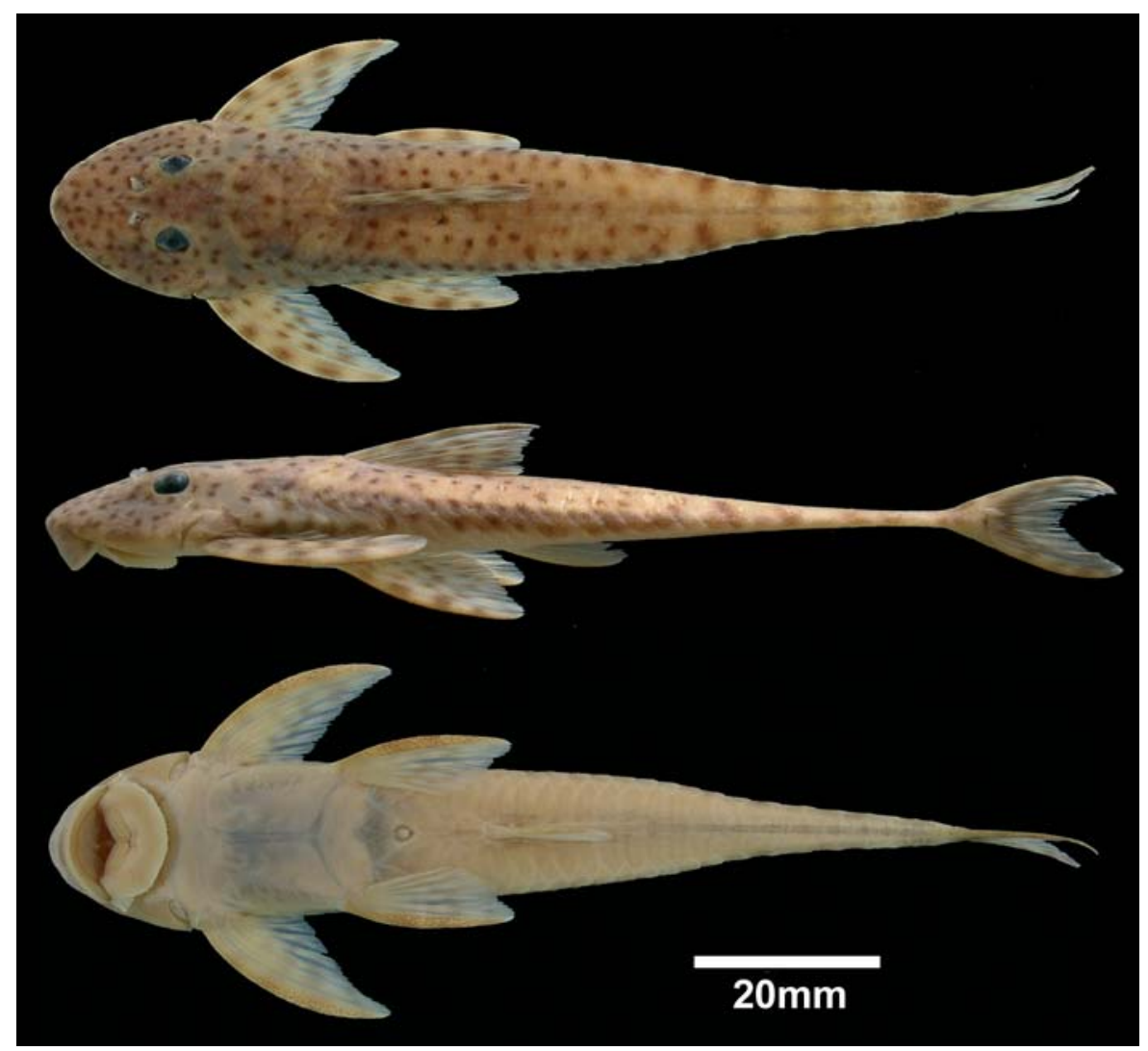

Fig. 1. Harttia merevari, MBUCV-V-26578, holotype, 99.4 mm of SL. Dorsal, lateral and ventral views. 
Table 1. List of the species of the genus Harttia, geographic distribution and abdomen type ( 1 - a stripe of tiny plates before the pelvic fins; 2 - three to five small plates at the scapular girdle level).

\begin{tabular}{|c|c|c|}
\hline Species & Distribution & Abdomen type \\
\hline H. carvalhoi Miranda Ribeiro, 1939 & S.E. Brazil & naked \\
\hline H. depressa Rapp-Py Daniel \& Oliveira, 2001 & N. Brazil & naked \\
\hline H. dissidens Rapp-Py Daniel \& Oliveira, 2001 & N. Brazil & covered \\
\hline H. duriventris Rapp-Py Daniel \& Oliveira, 2001 & N. Brazil & covered \\
\hline H. fowleri (Pellegrin, 1908) & French Guyana & covered \\
\hline H. garavelloi Oyakawa, 1993 & S.E. Brazil & naked \\
\hline H. gracilis Oyakawa, 1993 & S.E. Brazil & naked \\
\hline H. guianensis Rapp-Py Daniel \& Oliveira, 2001 & French Guyana & naked \\
\hline H. kronei Miranda Ribeiro, 1908 & S.E. Brazil & naked \\
\hline H. leiopleura Oyakawa, 1993 & S. E. Brazil & naked \\
\hline H. longipinna Langeani, Oyakawa \& Montoya-Burgos, 2001 & S.E. Brazil & covered \\
\hline H. loricariformis Steindachner, 1877 & S.E. Brazil & naked \\
\hline H. maculata (Boeseman, 1971) & Suriname and French Guyana & covered \\
\hline H. merevari Provenzano, Machado-Allison, Chernoff, Willink \& Petry, 2005 & Venezuela & naked \\
\hline H. novalimensis Oyakawa, 1993 & S.E. Brazil & naked \\
\hline H. platystoma (Günther, 1868) & Suriname and Venezuela & covered \\
\hline H. punctata Rapp-Py Daniel \& Oliveira, 2001 & N. Brazil & partially covered \\
\hline H. rhombocephala Miranda-Ribeiro, 1939 & S.E. Brazil & covered \\
\hline H. surinamensis Boeseman, 1971 & Suriname and French Guyana & covered \\
\hline H. torrenticola Oyakawa, 1993 & S. E. Brazil & naked \\
\hline H. trombetensis Rapp-Py Daniel \& Oliveira, 2001 & N. Brazil & naked $^{l}$ \\
\hline H. uatumensis Rapp-Py Daniel \& Oliveira, 2001 & N. Brazil & naked $^{2}$ \\
\hline
\end{tabular}

flap. Triangular plate anterior to each branchial opening, ornamented with small odontodes. Abdomen naked. Preanal region with two or three well developed plates (Fig. 2). Small specimens with two rectangular or square preanal plates preceded by one to seven small, irregularly shaped plates, in irregular arrangement. Holotype with three well defined preanal plates: middle triangular plate with apex directed to anus; sided by two large and rectangular plates. Each lateral preanal plate preceded by single, small, square plate (Fig. 2) Six or seven plates between pectoral and pelvic fins. 30 or 31 lateral plates. Anterior lateral plates carinate, forming double keel until plate 17 or 18, after which plates unite to form single keel to base of the caudal fin. Dorsal fin I,7 Pectoral fin I,6 Pelvic fin I,5. Anal fin I,5 Caudal fin i,12,i.

Coloration. Dorsal region of head and anterior part of body light or dark yellow with many black spots. Posterior region of body light or dark yellow with five transverse black bands; first two bands with diffused central portion (Fig. 1). Ventral region of head and body whitish. Dorsal, pectoral and pelvic fins with rectangular or square black blotches on rays; interradial membranes hyaline. Dorsal, pectoral and pelvic fin spines with four, five and four black blotches, respectively. Anal fin uniform whitish or yellow. Caudal fin with four black blotches on rays, and two transverse black bands. Anterior transverse band wide and well defined near base of middle rays; posterior band thin and weakly defined. Distal border of caudal fin hyaline

Habitat. Harttia merevari was captured very close to the top of Salto Pará (Fig. 3), a $50 \mathrm{~m}$ fall that separates the Caura River into upper and lower faunal sections (Chernoff et al., 2003).
The specimens were captured on and among relatively large rocks with flat surfaces, very near shore. The water was transparent with flow from fast to very fast. Podostemataceas were growing on the rocks. The depth at the colleting site was 1.5 meters on average.

Etymology. The species-group name, merevari, is the Ye-kuana name for the Caura River, and is treated here as a noun in apposition.

Comparisons. The largest known specimen of $H$. merevari is $99.4 \mathrm{~mm} \mathrm{SL}$ and this specimen as well as all other paratypes, which are smaller, have a naked abdomen. There is no evidence of plate development over the abdomen. The lack of

Table 2. Morphometric data of Harttia merevari expressed as percent of SL $(\mathrm{n}=8)$.

\begin{tabular}{lccccc}
\hline & Holotype & Maximum & Minimum & Mean & SD \\
\hline Standard length (mm) & 99.38 & 88.81 & 66.71 & & \\
Head length & 22.82 & 25.10 & 22.82 & 23.94 & 0.77 \\
Head depth & 8.91 & 9.66 & 8.91 & 9.18 & 0.27 \\
Snout length & 13.17 & 14.96 & 13.17 & 14.14 & 0.59 \\
Interorbital width & 5.41 & 6.26 & 5.37 & 5.83 & 0.35 \\
Orbital diameter & 4.18 & 4.64 & 4.18 & 4.34 & 0.16 \\
Predorsal length & 31.64 & 33.90 & 31.64 & 32.67 & 0.80 \\
Postdorsal length & 57.21 & 58.34 & 56.55 & 57.21 & 0.61 \\
Preanal length & 48.10 & 50.04 & 47.98 & 48.72 & 0.73 \\
Postanal length & 48.20 & 50.02 & 46.74 & 48.08 & 1.07 \\
Thoracic length & 14.97 & 15.93 & 14.97 & 15.43 & 0.31 \\
Abdominal length & 18.17 & 18.26 & 16.73 & 17.86 & 0.50 \\
Dorsal fin base & 11.64 & 11.70 & 10.60 & 11.08 & 0.42 \\
Dorsal spine length & 21.48 & 22.36 & 20.55 & 21.57 & 0.75 \\
Pectoral spine length & 23.59 & 23.59 & 20.51 & 21.94 & 0.92 \\
Pelvic spine length & 20.57 & 20.57 & 17.93 & 18.96 & 0.77 \\
Cleithral width & 19.87 & 21.65 & 19.87 & 20.39 & 0.56 \\
Caudal peduncle depth & 1.34 & 1.47 & 1.29 & 1.35 & 0.06 \\
\hline
\end{tabular}




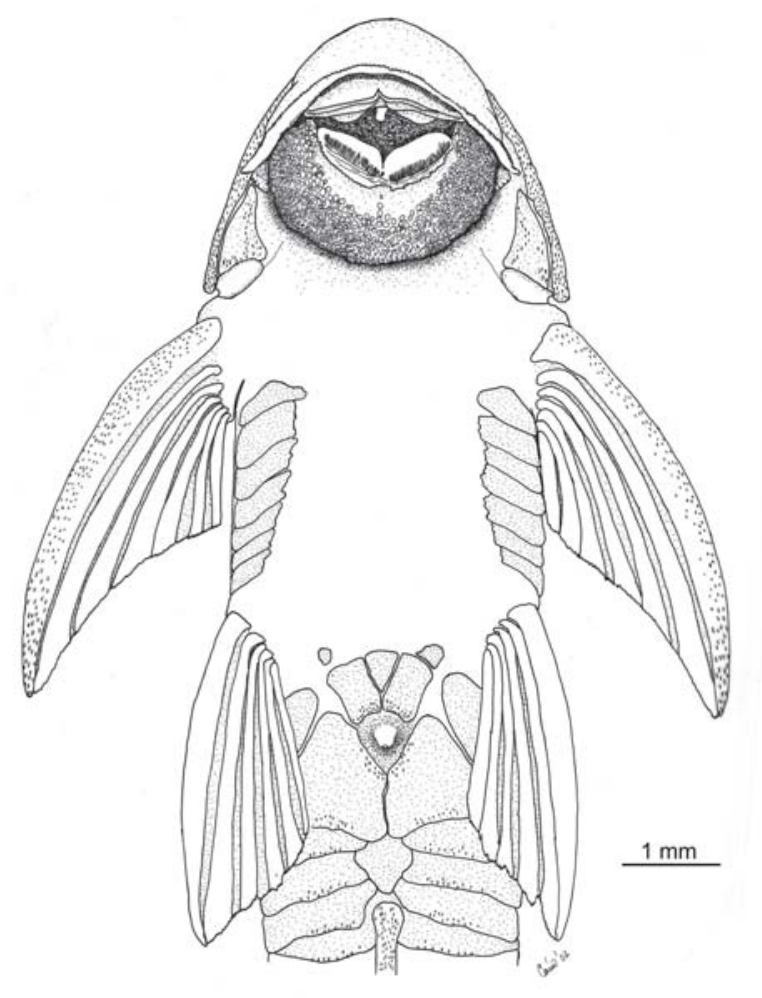

Fig. 2. Harttia merevari, MBUCV-V-26578, holotype, $99.4 \mathrm{~mm}$ SL. Ventral region showing the shape, relative size and/or arrangement of bony plates in front of the gill opening, between pectoral and pelvic fins, and preanal area. abdominal plates places $H$. merevari into a group of species of Harttia with naked abdomens: $H$. carvalhoi, $H$. depressa, $H$. garavelloi, H. gracilis, H. guianensis, H. kronei, $H$. leiopleura, $H$. loricariformis, $H$. novalimensis, and $H$. torrenticola. Harttia uatumensis probably should be considered a member of this group because this species possesses a single small patch of plates over the abdomen. Harttia carvalhoi, $H$. garavelloi, $H$. kronei, $H$. leiopleura, and $H$. novalimensis differ from $H$. merevari because each lacks the preanal plates present in the new species (Oyakawa, 1993; Langeani et al., 2001). In juveniles of $H$. torrenticola preanal plates are absent, adults have preanal plates but they are circular in shape, sparse, and reduced in number from 2 to 4 (Oyakawa, 1993). Harttia gracilis and H. loricariformis have two trapezoidal preanal plates, and 3 or 4 small plates anterior to those (Steindachner, 1877; Oyakawa, 1993). Additionally, $H$. leiopleura and $H$. novalimensis lack a bony plate in front of the gill opening; $H$. garavelloi does not have a maxillary barbel; and $H$. leiopleura does not have lateral plates between the pectoral and pelvic fins (Oyakawa, 1993). The external morphology of $H$. merevari resembles $H$. punctata but differs by the type of abdominal covering (naked $v s$. partially covered, respectively) and other morphometric and meristic measurements. Harttia depressa, H. guianensis, and $H$. uatumensis have naked abdomens as in $H$. merevari but differ in color pattern, body shape, and morphometric or meristic measurements.

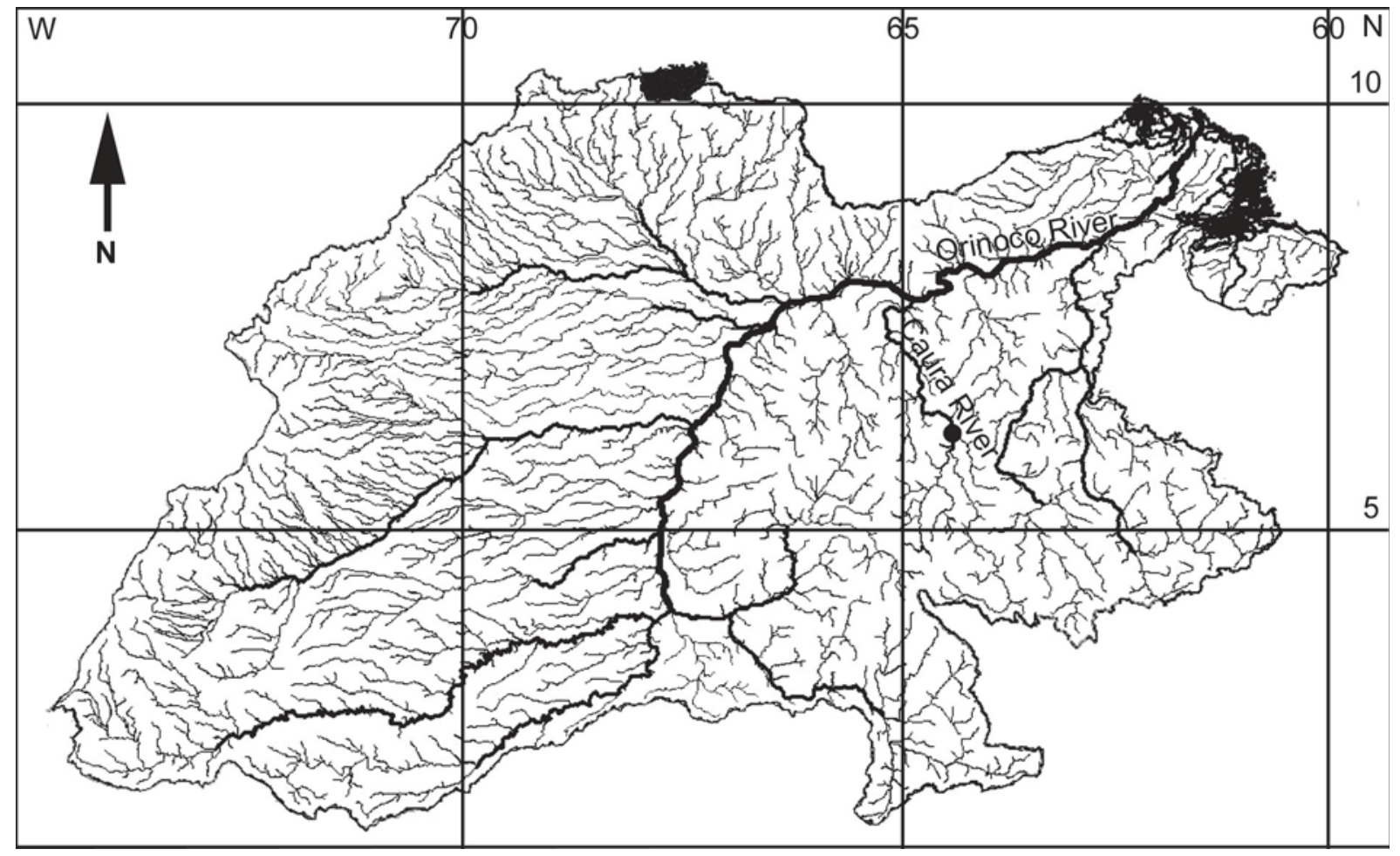

Fig. 3. Map of the Orinoco River drainage showing the type locality (solid circle) of Harttia merevari. 
Geographic Distribution. Harttia species are primarily distributed in the Amazon River basin and southeastern Brazil, but a few including the new species are found in the Guianas and the Orinoco River basin (Table 1). Harttia merevari extends the northwestern distribution of the genus to the northwestern slope of the Guyana shield draining into the Orinoco basin, being the first species to be recorded in this area (Fig. 3 ). If we consider the genus Cteniloricaria as a synonym of Harttia as proposed by Rapp Py-Daniel \& Oliveira (2001), the number of species assigned to Harttia reaches 22 species. Along the Guyana Shield, Harttia species are found in rivers in Suriname (Suriname River), French Guiana (Approuague and Sinnamary rivers) and Venezuela (Caura River and Cuyuni - Essequibo River drainage) draining the northern slope of the shield, and the Trombetas and Uatumã watersheds draining the southern slope of the Guyana Shield in Brazil (Boeseman, 1971; Machado-Allison et al., 2000; Rapp PyDaniel \& Oliveira, 2001) Further south, species have been reported from the Tapajós and Tocantins River basins on the northern slope of the Brazilian Shield (Rapp Py-Daniel \& Oliveira, 2001), São Francisco basin, upper Paraná and coastal drainages of southeastern Brazil (Steindachner, 1877; A. Miranda Ribeiro, 1908; P. Miranda Ribeiro, 1939; Oyakawa, 1993; Langeani et al., 2001) There is no particular distributional pattern among the species with or without naked abdomens; representatives of both groups are found along the Guyana shield and the southeastern region of Brazil.

\section{Acknowledgments}

We are especially grateful to Simón Caura and Kuyujani, especially A. and F. Rodríguez, for granting us permission and for arranging community support for fieldwork in their indigenous territories. We thank FONACIT, Instituto de Zoología Tropical-UCV, Asociación Venezolana para Conservación de Áreas Naturales, J. L. Suárez of Akanan Tours, L. Alonso and J. R. Montambault of Conservation International, and Mariapia Bevilacqua for logistical support. The Corporación Venezolana de Guayana allowed us to stay in their field camp at Entreríos. For help with collecting we thank A. Rojas, A. Marcano, B. Sidlauskas, and J. Sparks. Permits were kindly granted by: Consejo Nacional de Investigaciones Científicas y Tecnológicas; Instituto Nacional de Parques; Oficina de Asuntos Indígenas; Ministerio de Educación, Cultura y Deportes; Oficina Nacional de Diversidad Biológica del Ministerio del Ambiente y los Recursos Naturales; Servicio Autónomo de Pesca del Ministerio de Industria y Comercio. We are grateful to Mary Anne Rogers and the collections staff of the Field Museum. Research and fieldwork were supported by generous grants or donations from the Comer Science and Education Foundation, Rufford Foundation, J. Fahn and J and S. Goldstein. This work was partially supported by the All Catfish Species Inventory project funded by the U.S.A. National Science Foundation (DEB-0315963).

\section{Literature cited}

Boeseman, M. 1971. The "comb-toothed" Loricariinae of Surinam, with reflections on the phylogenetic tendencies within the family Loricariidae (Siluriformes, Loricariidae). Zoologische Verhandelingen, 116: 1-56.

Boeseman, M. 1976. A short review of the Surinam Loricariinae; with additional information on Surinam Harttiinae, including the description of a new species (Loricariidae, Siluriformes). Zoologische Mededelingen, 50(11): 153-177.

Chernoff, B., A. Machado-Allison, P. Willink, F. Provenzano \& P. Petry. 2003. The distribution of fishes and patterns of biodiversity in the Caura River Basin. Pp. 86-96 In: Chernoff, B., K. Riseng, A. Machado-Allison, J. R. Montambault (eds). A biological assessment of the aquatic ecosystems of the Rio Caura watershed, Venezuela. Bulletin of Biological Assessment 28, 284p.

Ferraris, C. J. Jr. 2003. Subfamily Loricariinae (Armored catfishes). Pp. 330-350 In: Reis R. E., S. O. Kullander \& C. J. Ferraris, Jr. (eds.). Check List of the Freshwater Fishes of South and Central America. Edipucrs, Porto Alegre. 729p.

Günther, A. 1868. Descriptions of freshwater fishes from Surinam and Brazil. Proceedings of the Zoological Society of London, 1868: 229-247.

Isbrücker, I. J. H. 1975. Metaloricaria paucidens, a new species and genus of mailed catfish from French Guiana (Pisces, Siluriformes, Loricariidae). Bulletin du Institut Royal des Sciences Naturelles de Belgique (Biologie), 50(4): 1-9.

Isbrücker, I. J. H. 1979. Descriptions préliminaires de nouveaux taxa de la famille des Loricariidae, Poissons-Chats cuirassés néotricaux, avec un catalogue critique de la sous-famille nominale (Pisces, Siluriformes). Revue Française d'Aquariologie et Herpetologie, 5(4): 86-117.

Isbrücker, I. J. H. 1980. Classification and catalogue of the mailed Loricariidae (Pisces, Siluriformes). Verslagen en Technische Gegevens, 22: 1-181.

Isbrücker, I. J. H. 2001. Nomenklator der gattungen und arten der harnischwelse, Familie Loricariidae Rafinesque, 1815 (Teleostei, Ostariophysi). Die Aquarien und Terrarienzeitschrift, Sonderheft Harnischwelse, 2: 25-32.

Isbrücker, I. J. H., I. Seidel, J. Pieter-Michels, E. Schraml \& A. Werner. 2001. Diagnose vierzehn neuer gattungen der Familie Loricariidae Rafinesque, 1815 (Teleostei, Ostariophysi). Die Aquarien und Terrarienzeitschrift, Sonderheft Harnischwelse, 2: 17-24.

Langeani, F., O. T. Oyakawa \& J. I. Montoya-Burgos. 2001. New species of Harttia (Loricariidae, Loricariinae) from the Rio São Francisco basin. Copeia, 2001: 136-142.

Machado-Allison, A., B. Chernoff, R. Royero-León, F. MagoLeccia, J.Velázquez, C.Lasso, H.López-Rojas, A.BonillaRivero, F. Provenzano \& C. Silvera. 2000. Ictiofauna de la cuenca del río Cuyuní en Venezuela. Interciencia, 25(1): 13-21.

Miranda Ribeiro, A. 1908. Peixes da Ribeira. Resultados de excursão do Sr. Ricardo Krone, membro correspondente 
do Museu Nacional do Rio de Janeiro. Kosmos, 5(2): 5 unnum. pp.

Miranda Ribeiro, P. 1939. Sobre o genero Harttia, Steind. (Peixes: Loricariidae). Boletim Biológico (Nova série), 4(1): 11-13.

Oyakawa, O. T. 1993. Cinco espécies novas de Harttia Steindachner, 1876 da região sudeste do Brazil, e comentários sobre o gênero (Teleostei, Siluriformes, Loricariidae). Comunicações do Museu de Ciências e Tecnologia da PUCRS, Série Zoologia, 6: 3-28.

Pellegrin, J. 1908. Description de deux poissons nouveaux de l'Amérique du Sud, de la famille des loricariidés. Bulletin de la Société Zoologique de France, 31: 124-127.
Rapp Py-Daniel, L. H. \& E. C. Oliveira. 2001. Seven new species of Harttia from the Amazonian-Guyana region (Siluriformes: Loricariidae). Ichthyological Exploration of Freshwaters, 12(1): 79-96.

Steindachner, F. 1877. Die Süsswasserfische des Südöstlichen Brazilien III. Situzungsberichte Akademie Wissenshaften Wien, 74(1. Abth.): 559-694.

Received July 2005

Accepted November 2005 